\title{
$\delta$-Sarcoglycan-deficient muscular dystrophy: from discovery to therapeutic approaches
}

\author{
Alison M Blain, Volker W Straub*
}

\begin{abstract}
Mutations in the $\delta$-sarcoglycan gene cause limb-girdle muscular dystrophy $2 F$ (LGMD2F), an autosomal recessive disease that causes progressive weakness and wasting of the proximal limb muscles and often has cardiac involvement. Here we review the clinical implications of LGMD2F and discuss the current understanding of the putative mechanisms underlying its pathogenesis. Preclinical research has benefited enormously from various animal models of $\delta$-sarcoglycan deficiency, which have helped researchers to explore therapeutic approaches for both muscular dystrophy and cardiomyopathy.
\end{abstract}

\section{$\delta$-Sarcoglycanopathy}

Historical and clinical aspects

In 1954, Walton and Nattrass described a group of patients who shared a similar pattern of proximal muscle weakness and whose symptoms could not be assigned to any of the known muscular dystrophies (MDs) of that time [1]. This highly heterogeneous group of patients was broadly characterised as having the limb-girdle muscular dystrophies (LGMDs). It was not until the discovery of dystrophin as the relevant protein missing in Duchenne muscular dystrophy (DMD) $[2,3]$ and the isolation of the dystrophin glycoprotein complex (DGC) [4] that this group was further stratified according to the molecular defect. It is now known that a subgroup of patients who present with an LGMD phenotype harbour mutations in genes encoding four of a family of six transmembrane proteins called the sarcoglycans (SGs).

LGMD2F was the fourth of the sarcoglycanopathies (LGMD2C to LGMD2F) to be characterised when the causative mutation in the $\delta$-SG gene was identified in a group of Brazilian LGMD patients with a DMD-like presentation whose disease was linked to a region on chromosome 5 (q33-34) [5-7]. Since then, a large number of mutations causing both LGMD2F and $\delta$-SG-associated cardiomyopathy have been described (Leiden Muscular Dystrophy database: http://www.dmd.nl/).

\footnotetext{
* Correspondence: Volker.Straub@ncl.ac.uk

Institute of Genetic Medicine, Newcastle University, International Centre for Life, Central Parkway, Newcastle upon Tyne, NE1 3BZ, UK
}

The age of onset in LGMD2F can vary from early childhood to adulthood. Most patients present with progressive weakness and wasting of the proximal muscles and elevated serum creatine kinase in the first decade of life [8]. General survival depends on cardiac and respiratory involvement and patients can die, sometimes even at early stages of the disease, because of severe dilated cardiomyopathy or chest infections and respiratory failure $[9,10]$. The diagnosis is based initially on examination of a muscle biopsy (which exhibits dystrophic features with reduced SG expression) and is confirmed by genetics [11]. Sarcoglycanopathy has, as a whole, a relatively low prevalence in nonconsanguineous populations $(2.27 / 100,000$ is a recent estimate) $[12,13]$, and whilst $\delta$-sarcoglycanopathy seems to be the rarest of this group of MDs [14], the understanding of its pathogenesis has implications for the development of therapeutic approaches for both patients with MD and patients with cardiomyopathy.

While patients with LGMD2F most commonly present with skeletal muscle weakness and only develop cardiomyopathy at later stages of their disease, $\delta$-SG mutations have also been found in patients with primary hereditary dilated cardiomyopathy with no significant skeletal muscle symptoms [15-18]. It has been suggested that at least one of these mutations could cause mild pathology in heterozygous carriers [18] or could even show a dominant mode of inheritance [15], but further evidence is necessary to clearly show that both recessive and dominant mutations are responsible for $\delta$-SG-deficient cardiomyopathy [19].
C Biomed Central

(c) 2011 Blain and Straub; licensee BioMed Central Ltd. This is an Open Access article distributed under the terms of the Creative Commons Attribution License (http://creativecommons.org/licenses/by/2.0), which permits unrestricted use, distribution, and reproduction in any medium, provided the original work is properly cited. 


\section{$\delta$-Sarcoglycan}

The $\delta$-SG gene contains nine exons spanning a $433-\mathrm{kb}$ region of genomic DNA. It encodes a $35-\mathrm{kDa}$, singlepass, type II transmembrane glycoprotein. To understand its role in the pathology of MD and cardiomyopathy, it is important to consider it as one of a family of six SG proteins, four of which, $\alpha-, \beta-, \gamma-$ and $\delta$-SG, are associated with forms of autosomal recessive LGMD and cardiomyopathy, and one of which, $\varepsilon$-SG, is associated with a form of myoclonus dystonia, whereas no disease has been associated with $\zeta$-SG to date. $\gamma$ - and $\delta$-SG share a similar structure with a conserved sequence in the $\mathrm{C}$-terminal domain, which is essential for their localisation to the plasma membrane, and an $\mathrm{N}$-terminus that is important for SG-SG interaction [20]. It is generally accepted that, in skeletal muscle, at least $\alpha-, \beta-$, and $\gamma$-SG form a tetrameric complex with $\delta$-SG. There is also evidence that $\varepsilon$ SG can replace $\alpha$-SG in striated muscle to form a second SG complex [21].

Coimmunoprecipitation studies have shown a strong interaction between $\delta$ - and $\beta$-SG [22], which is thought to form a central core that is necessary for the delivery and retention of other SGs to the cell membrane $[23,24]$. This hypothesis is supported by the fact that patients with mutations in either $\delta$ - or $\beta$-SG appear to have a complete loss or a strong reduction of the whole SG complex on examination of muscle biopsy samples $[14,25,26]$. It is thought that in smooth muscle, $\varepsilon$-SG functionally replaces $\alpha-S G$ to form a unique complex analogous to that in skeletal muscle $[27,28]$. The more recent discovery of $\zeta$-SG in skeletal and smooth muscle [29] has led to the prediction of other models of SG complex conformation [30-32].

The various forms of SG complexes all seem to form an integral part of the dystrophin-glycoprotein complex (DGC) [33], the function of which has best been characterised in skeletal muscle, where it forms a mechanosignalling link between the F-actin cytoskeleton and the extracellular matrix. The DGC confers structural stability to the sarcolemma, and dissociation of the complex by loss of one of its components renders the muscle more susceptible to contraction-induced damage. Dissociation of the DGC complex is also thought to have widespread implications for a number of signalling processes, as it is closely associated with a diverse range of molecules, such as neuronal nitric oxide synthase (nNOS) [34-36] and members of the integrin family of signalling proteins [37-39].

An alternative splice variant of $\delta$-SG, SG3, has been localised to the membrane of the sarcoplasmic reticulum (SR), where it forms a complex homologous to that at the sarcolemma [40]. It is hypothesised that this SR complex plays a role in regulating calcium movement across the SR membrane, which is important for the maintenance of calcium homeostasis.

Although the SGs are expressed primarily in muscle, there is evidence that they are also expressed in other tissues, such as myelin [41], adipocytes [42], kidney and lung epithelial cells [28] and the retina [43]. The functional relevance of SG expression in these tissues is currently unclear, however, as patients with LGMD2F do not appear to show neuropathic, central nervous system or cognitive impairments, nor do they have any overt aberrations in glucose metabolism or kidney and lung function.

\section{Animal models of $\boldsymbol{\delta}$-SG deficiency}

There are a number of animal models of $\delta$-sarcoglycanopathy that have aided in the understanding of its pathogenesis (Table 1). The cardiomyopathic hamster is the oldest and most well-characterised of these.

\section{The cardiomyopathic hamster: a model of sarcoglycanopathy in cognito}

The BIO 14.6 hamster strain was established in 1962 [44] and was studied for over three decades as a model of cardiomyopathy, but it was only after the discovery of the causative mutation in LGMD2F patients that two independent laboratories demonstrated a large deletion in the 5 ' end of the $\delta$-SG gene in these animals $[45,46]$. The hamster was therefore heralded as the first animal model of sarcoglycanopathy.

Like the majority of LGMD2F patients, the hamster lacks sarcolemmal $\delta$-SG expression and has a concomitant reduction in the other components of the SG complex [47]. Cardiac damage could be seen in the heart from 5 weeks of age, indicating the early onset of pathology in cardiac muscle compared to skeletal muscle [47]. Assessment of cardiac haemodynamics in the hamster over its lifetime (240 days) indicates a cardiomyopathic phenotype with decreased stroke volume and cardiac output $(\mathrm{CO})$ as well as increased ventricular mass [48].

At least three additional strains of hamsters, the TO-2, CHF147 (formally VMX7.1) and J2N-k strains, have since arisen from the original BIO 14.6 strain. The TO2 strain is particularly interesting, as these hamsters exhibit a more severe cardiomyopathy and a shorter lifespan than their BIO 14.6 counterparts. In addition, while both strains share the same 30-kb deletion in the $\delta$-SG gene, the BIO 14.6 strain develops a hypertrophic cardiomyopathy, whilst the TO-2 hamsters tend to develop a severe dilated cardiomyopathy with a predominantly necrotic mode of pathology [49,50]. This presents the intriguing possibility of the presence of a genetic modifier within the TO-2 hamster. Indeed, a 
Table 1 Animal models of $\delta$-sarcoglycan deficiency ${ }^{a}$

\begin{tabular}{|c|c|c|c|}
\hline Species & Genesis & $\begin{array}{l}\text { Effect on protein/DGC } \\
\text { components }\end{array}$ & Phenotype \\
\hline \multicolumn{4}{|l|}{ Hamster } \\
\hline BIO 14.6 & $\begin{array}{l}\text { Naturally occurring, autosomal recessive } \\
\text { mutation (30-kb deletion in exons } 1 \text { and 2) [44] }\end{array}$ & $\begin{array}{l}\text { Loss of } \delta \text { - and } \beta \text {-SG } \\
\text { Reduction of } \alpha \text {-and } \gamma \text {-SG [47,54] } \\
\text { Reduction in } \alpha \text {-dystroglycan [47] } \\
\text { Normal dystrophin }\end{array}$ & $\begin{array}{l}\text { Compensatory hypertrophic CM leading to } \\
\text { dilated CM } \\
\text { Sarcolemmal damage (increased EBD uptake) }\end{array}$ \\
\hline TO-2 & Cross-breeding (30-kb deletion in exons 1 and 2) & $\begin{array}{l}\text { Complete loss of SG complex } \\
\text { Translocation of dystrophin to } \\
\text { cytoplasm [150] }\end{array}$ & $\begin{array}{l}\text { Severe dilated CM } \\
\text { LV dysfunction from } 8 \text { weeks [151] } \\
\text { Gait disturbances [152] }\end{array}$ \\
\hline$J 2 N-k$ & $\begin{array}{l}\text { Cross-breeding (BIO } 14.6 \times \text { golden hamster, } \\
\text { then consecutive sib mating) [153] }\end{array}$ & Uncharacterized? & $\begin{array}{l}\text { Cardiac contractile dysfunction } \\
\text { Dilated CM from } 20 \text { weeks [90] } \\
\text { Elevated CK level }\end{array}$ \\
\hline $\begin{array}{l}\text { UMX7.1 or } \\
\text { CHF147 }\end{array}$ & Cross-breeding (BIO $14.6 \times$ normal controls) [154] & Uncharacterized? & $\begin{array}{l}\text { Dilated CM } \\
\text { Progressive LV dysfunction [155] } \\
\text { Reduced life expectancy ( } 190 \text { days) } \\
\text { Early skeletal muscle pathology ( } 10 \text { to } 15 \text { days) } \\
\text { Focal necrosis } \\
\text { Unselective muscle involvement }\end{array}$ \\
\hline \multicolumn{4}{|l|}{ Mouse } \\
\hline $\begin{array}{l}\text { Sgcd }^{--} \\
\text {(C57BL6 } \\
\text { background) }\end{array}$ & $\begin{array}{l}\text { Transgenic (vector-mediated, knockdown- } \\
\text { targeted replacement of exon 2, which } \\
\text { encodes the entire TM domain and part of the } \\
\text { intracellular domain) [57] }\end{array}$ & $\begin{array}{l}\text { Loss of whole SG complex and } \\
\text { sarcospan }\end{array}$ & $\begin{array}{l}\text { Limb-girdle pattern of muscle involvement } \\
\text { Focal areas of necrosis } \\
\text { Cardiomyopathy from } 8 \text { weeks, ECG } \\
\text { abnormalities } \\
\text { Increased probability of spontaneous death } \\
\text { at } 6 \text { months }\end{array}$ \\
\hline $\begin{array}{l}\mathrm{Sgcd}^{-1} \\
(129 \mathrm{SvJ} / \\
129 \mathrm{SvEms-} \\
+{ }^{\text {Ter } / \mathrm{J}} \\
\text { background) }\end{array}$ & $\begin{array}{l}\text { Transgenic (vector-mediated replacement of } \\
\text { exon 2; homozygotes generated from } \\
\text { heterozygote matings) [56], resultant } \delta \text {-SG } \\
\text { mRNA lacking 201-bp region. }\end{array}$ & $\begin{array}{l}\text { Loss of all SGs (including } \varepsilon \text {-SG) in } \\
\text { muscle microsomes on } \\
\text { immunoblot despite normal levels } \\
\text { of transcription }\end{array}$ & $\begin{array}{l}\text { Premature death: only 50\% survival at } 28 \\
\text { weeks } \\
\text { Elevated CK } \\
\text { Regional degeneration/regeneration, } \\
\text { calcification, inflammatory infiltration, } \\
\text { perivascular fibrosis and increased EBD } \\
\text { uptake on muscle histology } \\
\text { Cardiac histological changes at } 12 \text { weeks } \\
\text { Reduced force generation in response to } \\
\text { eccentric contractions }\end{array}$ \\
\hline \multicolumn{4}{|l|}{ Drosophila } \\
\hline Line 840 & $\begin{array}{l}\text { Engineered (large deletion by P element } \\
\text { excision) [65] }\end{array}$ & $\begin{array}{l}\text { Loss of whole } \delta \text {-SG protein } \\
\text { Effect on other DGC components } \\
\text { uncharacterized }\end{array}$ & $\begin{array}{l}\text { Shortened lifespan } \\
\text { Progressive impairment in locomotive ability } \\
\text { Reduced heart tube function } \\
\text { Abnormal flight muscles } \\
\text { No regeneration }\end{array}$ \\
\hline Line 28 & $\begin{array}{l}\text { Engineered (small deletion by } P \text { element } \\
\text { excision) [65] }\end{array}$ & $\begin{array}{l}\text { Loss of cytoplasmic region of } \\
\delta \text {-SG only } \\
\text { Effect on other DGC components } \\
\text { uncharacterized }\end{array}$ & $\begin{array}{l}\text { Mild } \\
\text { Near-normal lifespan } \\
\text { Normal cardiac function } \\
\text { Normal locomotive function }\end{array}$ \\
\hline \multicolumn{4}{|l|}{$\begin{array}{l}\text { Caenorhabditis } \\
\text { elegans }\end{array}$} \\
\hline F07H5.2 & $\begin{array}{l}\text { RNA interference (animals fed or injected with } \\
\text { dsRNA corresponding to 500- to 700-bp exon- } \\
\text { rich region) [64] }\end{array}$ & Uncharacterized? & $\begin{array}{l}\text { Phenotype similar to dystrophin KO (dys-1) } \\
\text { (bending of head with forward movement, } \\
\text { hyperactivity, hypercontraction) }\end{array}$ \\
\hline \multicolumn{4}{|l|}{ Zebrafish } \\
\hline N/A & Morpholino knockdown of $\delta$-SG [67] & $\begin{array}{l}\text { Downregulation of } \delta \text {-, } \beta \text { - and } \\
\gamma \text {-SGs }\end{array}$ & $\begin{array}{l}\text { Disorganized muscle development } \\
\text { Reduced movement } 5 \mathrm{dpf}\end{array}$ \\
\hline N/A & Morpholino knockdown of $\delta$-SG [66] & Uncharacterized? & $\begin{array}{l}\text { Severe abnormality of skeletal and cardiac } \\
\text { muscle } \\
\text { Delayed cardiac development and abnormal } \\
\text { cardiac differentiation } \\
\text { Dead by } 5 \mathrm{dpf}\end{array}$ \\
\hline
\end{tabular}


missense mutation in the mitochondrial DNA of hypertrophic TO-2 hamsters, which is not present in the BIO 14.6 strain, has been identified [51]. Other mapping approaches have also led to the identification of genetic modifiers of fibrosis, membrane leak and muscle-specific modifying loci in another mouse model of sarcoglycanopathy $[52,53]$. Genetic modifiers may therefore partly account for heterogeneity in both clinical presentation and muscle involvement in patients with LGMD2F.

Another interesting difference between these two strains of hamsters is the expression pattern of the SGs. Whilst the cardiac muscle of BIO 14.6 stains weakly for $\alpha$ - and $\gamma$ SGs, the TO-2 strain does not stain for any of the SGC components [54]. The TO-2 strain therefore provides a 'cleaner' background for the assessment of transduction efficacy in gene transfer studies. Again, genetic modifiers may account for this discrepancy between strains of $\delta$-SGdeficient hamsters and also in the rare patients who display a milder phenotype with partial retention of the SG complex at the sarcolemma [55].

\section{The $\delta$-sarcoglycan-null mouse}

While the hamster remains a useful, naturally occurring model for $\delta$-SG-deficient cardiomyopathy, $\delta$-SG-deficient $\left(\mathrm{Sgcd}^{-1-}\right)$ mice have also been generated $[56,57]$. From a young age, these mice develop typical histological features of MD in most of their skeletal muscles. As in the hamster, the diaphragm shows a particularly severe pathology with abnormalities evident from as early as 4 weeks of age [57].

$\mathrm{Sgcd}^{-1-}$ mice also develop cardiomyopathy from around 8 weeks of age, with focal areas of fibrosis that were thought to be related to abnormalities in the coronary vasculature [57]. The primacy of these vascular events in the development of MD is contentious, however. Functionally, 8-week-old $S g c d^{-1-}$ mouse hearts show electrocardiographic abnormalities [57], and by 16 weeks, they develop a well-compensated cardiomyopathy, with reduced contractility but preserved ejection fraction (EF) and CO [58,59]. However, by 32 weeks of age, there is a deterioration in pathology such that the left (and right) EF is significantly reduced, with evidence of right ventricular dilation, which is indicative of pulmonary dysfunction [60]. Pulmonary dysfunction is consistent with the severe pathology observed in the diaphragms of $\mathrm{Sgcd}^{-1-}$ mice and is also a feature of advanced stage LGMD $[9,61]$. The $S g c d^{-/-}$mouse, therefore, like the hamster, recapitulates many of the important features of the human disease, making it a useful preclinical research tool.

\section{Fly, worm and fish models of $\delta$-SG deficiency}

Despite their early evolutionary divergence from mammals, $\delta$-SG deficiency orthologues have been identified in Drosophila, zebrafish and the nematode Caenorhabditis elegans [62-64] (Figure 1). These organisms are easy to manipulate genetically while being cheap to breed and maintain. They have been particularly useful in indicating the protein domains that are most important to $\delta$-SG function [65] and for investigation of the developmental expression of $\delta$-SG in different tissues $[63,66,67]$. RNA interference work in C. elegans has also generated important data suggesting the involvement of calcium channel disruption in the pathology of MD [68].

\section{Putative disease mechanisms}

\section{Calcium overload: a unifying mechanism?}

Studies in animal models of $\delta$-sarcoglycanopathy have revealed a baffling array of pathological changes, which have been targeted by various drug therapies (Figure 2). However, many of these mechanisms can be traced to an upstream elevation in intracellular calcium. Indeed, calcium overload is sufficient to elicit a MD phenotype in mice [69]. In $\delta$-sarcoglycanopathy, calcium overload is thought to occur through two main mechanisms: through membrane tears due to loss of sarcolemmal stability and through abnormalities in calcium channels of the sarcolemmal or sarcoplasmic reticulum number or function.

\section{Loss of membrane integrity}

The membrane instability theory of muscle pathology predicts that the loss of components of the DGC leads to susceptibility to contraction-induced damage, increased influx of calcium and ultimately cell degeneration. There is evidence to suggest that this is a common primary pathomechanism in a number of MDs [70]. More specifically, membrane fragility and abnormalities (' $\Delta$ lesions') have been noted in patients and in animal models of sarcoglycanopathy [71,72]. A study using the TO-2 hamster suggested that this sarcolemmal fragility is due to a secondary loss of dystrophin [73]. Dystrophin loss is not a feature of all strains of $\delta$-SG hamster [47], however, suggesting that loss of SGC alone is sufficient to produce sarcolemmal instability. Sarcolemmal damage can be easily assayed in animal models by means of Evans blue dye (EBD), which cannot enter intact cells. Mouse and hamster models of $\delta$-sarcoglycanopathy both show evidence of increased EBD uptake, in both heart and skeletal muscles $[47,57,58]$.

\section{Calcium channel dysregulation}

Besides the structural role of $\delta$-SG, it has been proposed that loss of the components of the DGC can produce a more specific alteration in calcium influx via disruption of calcium channels. There have been no studies conducted to date suggesting a direct interaction between the SG complex and calcium channels; however, electrophysiological studies of myocytes isolated from dystrophic hamsters have shown the presence of abnormal 


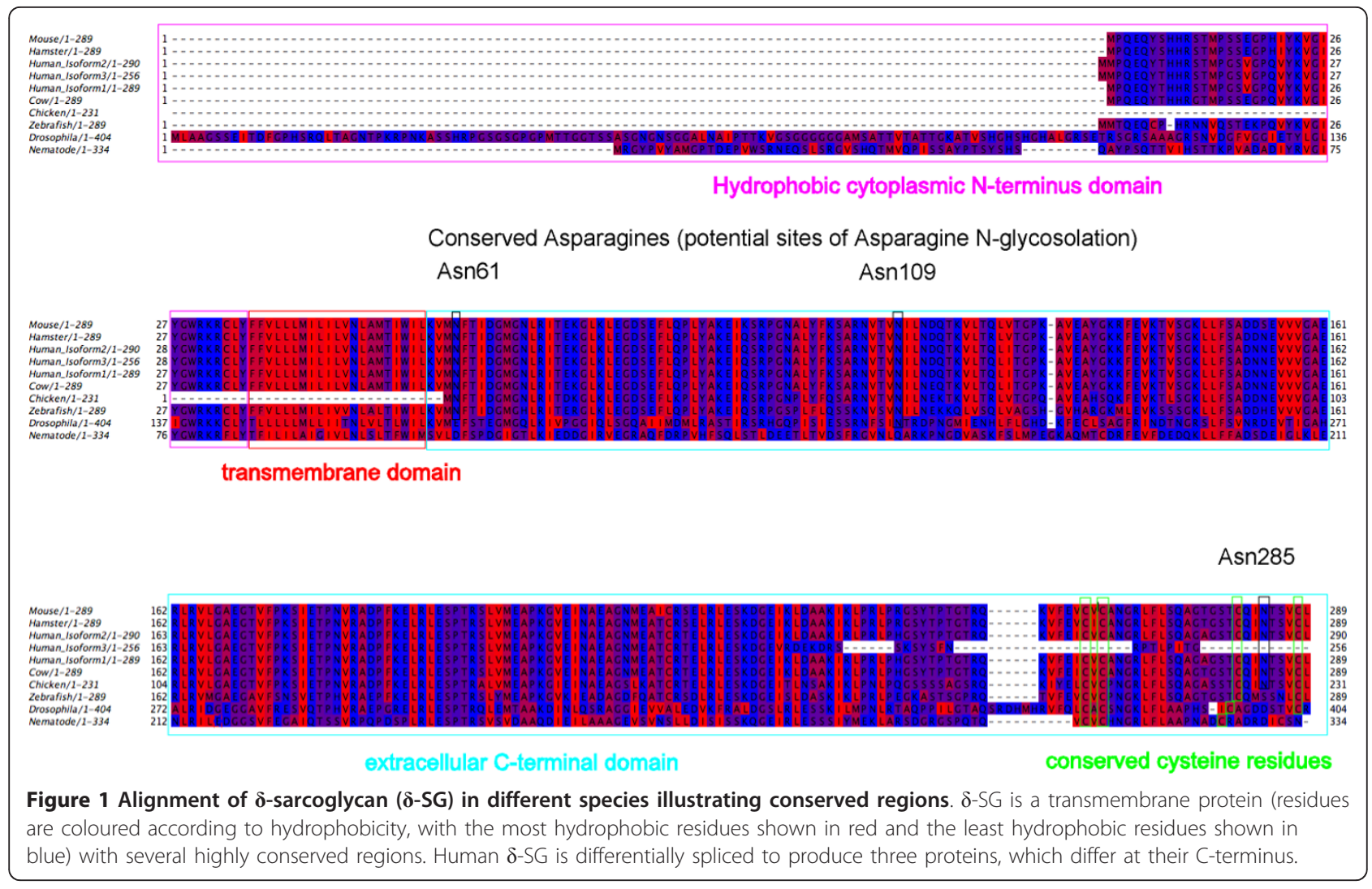

calcium currents and increased intracellular calcium levels even in the absence of mechanical stress [74]. Attempts to identify the origin of these abnormal currents in cardiomyocytes from $\delta$-SG-deficient hamsters have yielded contradictory evidence. While it has been suggested that L-type calcium channels (LCCs), the predominant calcium channel in the heart, are neither more active nor overexpressed in the hamster [75-77], LCC antagonists (tranilast, diltiazem and FK506) have had a protective effect on muscle [76]. Also, increased enrichment of the pore-forming subunit of the LCC has been found in microsomes of myopathic hearts, although not from ventricular myocytes [78].

Other electrophysiological studies have identified T-type calcium channels as being important in the abnormal calcium homeostasis of $\delta$-SG-deficient hamster cardiomyocytes $[79,80]$. Indeed, T-type channel blockers that have low LCC activity (efonidipine and mibefradil) improve cardiac function in the hamster [81,82]. However, a comparison of mibefradil and verapamil efficacy in preventing the dystrophic process in hamsters showed no benefit of mibefradil [83].

In skeletal muscle, the calcium entry required for contractile activity enters via store-operated and stretchactivated calcium channels (SOCs and SACs, respectively) [84]. Elevated SAC currents have been detected in $\delta$-SG-deficient myotubes [85], and although transient receptor potential canonical 1 (TRPC1) has been suggested as a candidate SAC involved in the pathogenesis of the $m d x$ mouse model of DMD and cardiomyopathy $[86,87]$, there have been no studies of this channel in $\delta$-sarcoglycanopathy.

Some evidence points towards there being abnormalities in internal calcium homeostasis across the SR membrane in $\delta$-SG-deficient animals $[40,88]$. Indeed, a recent study of $\mathrm{Sgcd}^{-1-}$ mice suggested that two isoforms of $\delta$-SG (SG1 and SG3) play a role in the stabilisation of $\gamma$-SG and sarcospan expression in the T-tubule and SR membrane [89]. The authors showed that $\mathrm{Sgcd}^{-/-}$mice possess a conformational change in SERCA1 $\mathrm{Ca}^{2+}$ ATPase (sarco(endo)plasmic reticulum ATPase 1), which alters resting calcium homeostasis. Additionally, it has been demonstrated that SG3 is located in close proximity to voltage-sensing dihydropyridine receptors that play a role in regulating calcium release via ryanodine receptors in the SR [40]. These findings may explain earlier observations in the J2N-k hamster which suggested that SR abnormalities contribute to contractile dysfunction in these animals [90]. Therapeutic strategies for $\delta$-sarcoglycanopathy, then, should perhaps aim to correct internal calcium homeostasis as well as reduce calcium influx across the sarcolemma. 


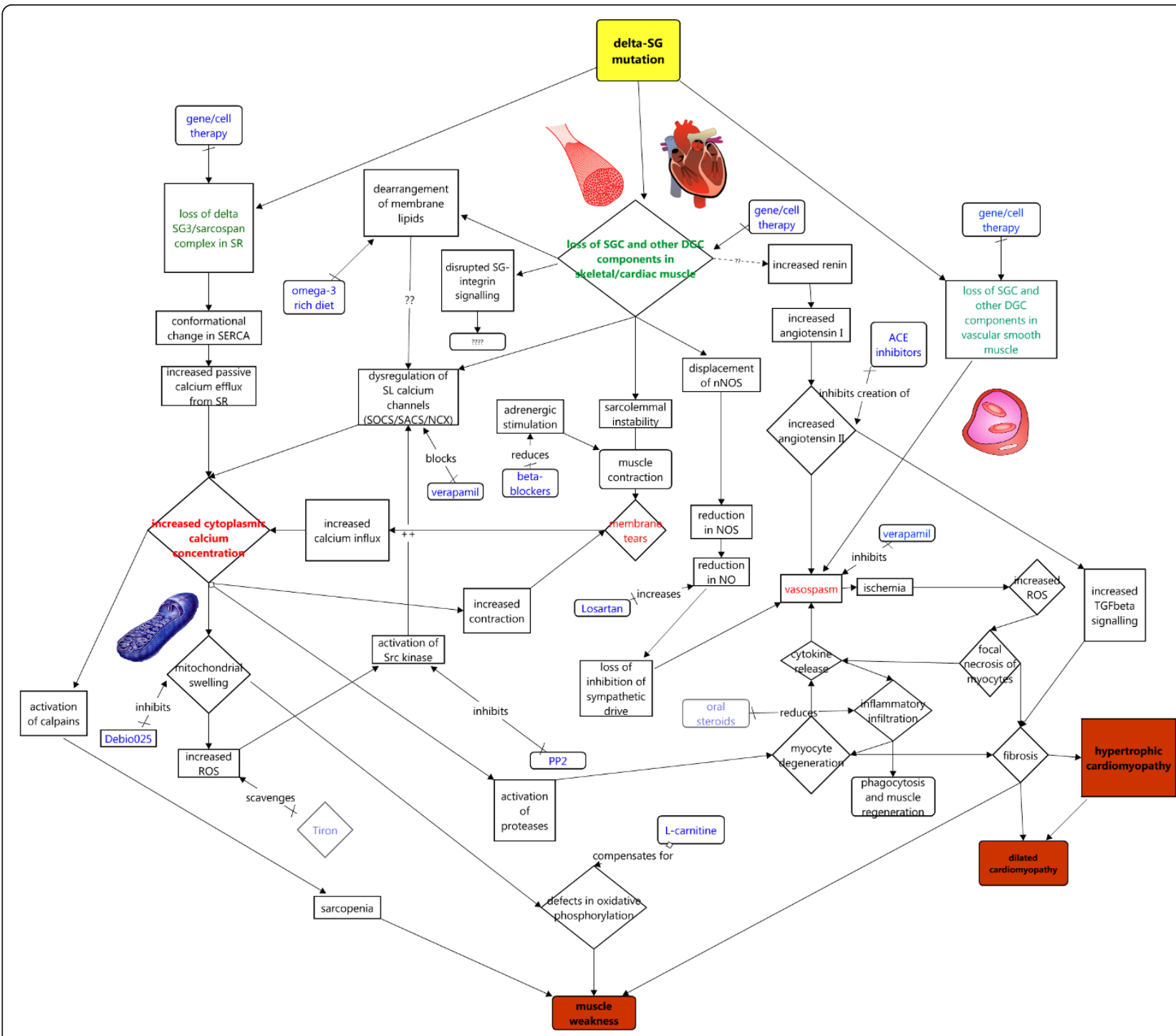

Figure 2 Putative pathomechanisms involved in $\delta$-sarcoglycanopathy revealed by studies of the animal models of the disease. Disease mechanisms suggested by animal studies, and their possible relationships to each other, are presented schematically. Pivotal events in the development of pathology are highlighted in red, and potential therapies are shown in blue. Faded boxes represent therapies that have had some success in animal models of other muscular dystrophies or are currently used in Duchenne muscular dystrophy and as such may be potentially useful in the treatment of $\delta$-sarcoglycanopathy.

\section{Downstream consequences of calcium overload Oxidative Stress and mitochondrial dysfunction}

Mitochondrial swelling is commonly observed in MD, and early electromicroscopy studies in tissues and cells isolated from the cardiomyopathic hamster revealed several abnormalities in the fine structure of the mitochondria [91,92]. Other studies have suggested, however, that these changes are secondary to increased intracellular calcium and that mitochondrial swelling due to calcium overload can lead to myocyte necrosis [93-96]. Although latent mitochondrial dysfunction can be observed at high heart rates in younger $\delta$-SG-deficient hamsters, it is ameliorated by verapamil, lending further support to calcium involvement [97]. Increased reactive oxygen species (ROS) production due to mitochondrial overload is also thought to cause activation of Src kinase and subsequent activation of TRPC1 at the sarcolemma [86]. Mitochondrial dysfunction may therefore feed back to calcium channels on the sarcolemma to exacerbate already elevated intracellular calcium levels. ROS scavengers such as tiron, which have already been demonstrated to have some success in $m d x$ mice [86], may therefore be useful in halting this vicious cycle in $\delta$-sarcoglycanopathy. 
Recently, it has been demonstrated that overactivation of the mitochondrial transition pore (MPTP) in $\delta$-SGdeficient hamster cardiomyocytes renders the mitochondria of these hamsters leaky to calcium influx and susceptible to mitochondrial swelling [93]. Mitochondrial swelling has been targeted directly as a strategy for the treatment of patients with LGMD2F. Deletion of the gene encoding cyclophilin D, a component of MPTP, renders mice unsusceptible to mitochondrial swelling and ameliorates pathology in $\mathrm{Sgcd}^{-/-}$mice [98]. Indeed, treatment with a cyclophilin D inhibitor (Debio-025) is effective in reducing pathology in $\mathrm{SgCd}^{-1-}$ mice and also in the $m d x$ mouse model of DMD [98]. This may suggest that mitochondrial swelling is a common downstream cause of pathology in both LGMD2F and DMD.

In addition to calcium overload, defects in carnitine transport have been implicated in mitochondrial dysfunction in $\delta$-sarcoglycanopathy. Reduced carnitine levels can be detected at a prepathological time point in $\delta$-SG-deficient hamsters [99]. L-Carnitine facilitates the transport of fatty acids into mitochondria for energy production via oxidation, and carnitine deficiency syndrome results in muscle weakness, so it can be envisaged that deficiency in this molecule could account for some of the symptoms of LGMD2F. There have been a number of studies that have suggested that supplementation with L-carnitine or propionyl-L-carnitine can have positive effects on $\delta$-SG mouse hearts and skeletal muscle, in terms of both energy metabolism and pathology [100-106]. Similarly, other dietary supplements such as selenium, taurine and coenzyme $Q_{10}[106,107]$, as well as mild exercise regimes [108-110], have shown a beneficial effect on mitochondrial function and hence muscle pathology in the cardiomyopathic hamster, providing further evidence of lifestyle factors which may influence disease progression. Therapeutically, mitochondrial dysfunction may therefore represent a rather downstream but relatively easily targeted disease mechanism.

\section{Vascular dysfunction}

Although $\delta$-SG is expressed in vascular smooth muscle, vascular dysfunction as a primary cause of MD pathology is controversial. Adenoviral transfer of $\delta$-SG into $S g c d^{-1-}$ mice was sufficient to prevent MD, although vascular smooth muscle was not transduced, suggesting that vascular dysfunction is not a primary cause of pathology [111-113]. Early data which showed that the vasodilator verapamil could ameliorate 'microinfarcts' and focal areas of fibrosis in the $\mathrm{Sgcd}^{-/-}$mouse and the BIO 14.6 Syrian hamster [112-115] was originally taken as evidence in support of the vasospasm theory. However, the interpretation of these data is muddied by the fact that verapamil can affect LCCs in cardiomyocytes as well as in smooth muscle and hence may normalise a myocyte-intrinsic defect [116]. In support of this hypothesis, a $\gamma$-SG-deficient mouse with no perturbation in vascular smooth muscle SGs develops cardiomyopathy and vasospasms, presumably secondary to cardiomyocyte degeneration [117]. Furthermore, Shimizu et al. [118] showed that progressive myocyte loss is responsible for deterioration of cardiac function in BIO TO-2 hamsters, while impaired vascular regeneration may be responsible for progressive remodelling. The general view is therefore that vascular spasm is an important mechanism that contributes to the progression of LGMD2F, but that it should be seen as a secondary consequence of myocyte injury through calcium-activated processes such as increased proteolysis by calpains [119] and mitochondrial dysfunction.

One of the factors that may make $\delta$-SG-deficient animals particularly susceptible to vasospasm and focal ischaemia is disruption of nNOS. Displacement of nNOS from the sarcolemmal membrane has been noted in patients with DMD and more recently in LGMD patients with SG mutations and animal models of sarcoglycanopathy $[35,120]$. nNOS is associated with dystrophin at the sarcolemmal membrane [34] and generates $\mathrm{NO}$, a molecule with a pivotal role in modulating blood flow [121], through a calcium-dependent process. It is thought that disruption of nNOS renders the muscle more susceptible to focal ischaemia and damage by superoxides $[121,122]$. That $n N O S$ has a role in vascular dysfunction in $\delta$-sarcoglycanopathy is further evidenced by the observation that drugs which increase myocardial NO (for example, simvastatin, losartan) also improve cardiomyopathy in the hamster [123-125].

Overactivation of the renin-angiotensin system may also contribute to vasospasm in the $\delta$-SG-deficient hamster [123,126-128]. Indeed, the use of angiotensinconverting enzyme inhibitors (ACEi) and aldosterone antagonists has demonstrated some success in ameliorating cardiac and diaphragmatic pathology and function in both hamster and mouse models of $\delta$-SG deficiency [129-132]. ACEi have well-established vasodilative actions and form part of the cardiac management for LGMD2F patients. They may have additional benefit, however, because of their less well-characterised antifibrotic actions [133].

\section{Therapeutic strategies}

\section{Current therapeutic strategies}

There is currently no cure for LGMD2F and other muscular dystrophies involving the DGC. Current clinical management is similar to that described in published care guidelines for DMD $[11,134]$ and concentrates on management of cardiac and respiratory symptoms. Steroids are not routinely used in the treatment of 
LGMD2F, however, despite anecdotal reports of their efficacy in sarcoglycanopathies.

\section{Replacing defective genes or proteins Viral vector-mediated gene transfer}

Intuitively, correction of the genetic defect or replacement or substitution of $\delta$-SG protein is the simplest approach to tackling LGMD2F. Indeed, $\delta$-SG has a much shorter coding sequence than dystrophin and as such may not lead to many of the difficulties that are encountered in gene therapy for DMD. Studies in $m d x$ mice, however, have shown that cardiac tissue is particularly difficult to target and skeletal muscle-centric treatment carries the danger of producing a more aggressive cardiac phenotype [135].

Intramuscularly administered adeno-associated viral (AAV) vectors have successfully restored cardiac and skeletal muscle SG membrane proteins in the $\delta$-SG-deficient mouse and hamster, slowing functional deterioration [136-140]. Furthermore, it has been demonstrated that AAV transduction can be efficient and long-lived [141]. From a translational point of view, therapies that can be delivered systemically are more feasible, and it has been shown that systemically delivered AAV vectors are also efficient in reconstituting the SGC while reducing functional deterioration in the cardiac muscle of $\delta$-SG-null mice and, encouragingly, in relatively old BIO 14.6 hamsters $[142,143]$. Work using virus display peptide libraries has suggested that systemically administered AAV vectors can also be specially selected to 'home' in to specific tissues, allowing greater control of where the vector is delivered [144].

Despite these encouraging results from various animal studies, the therapeutic approach is not easily translatable to humans because of potential immunogenic and toxic complications; however, there have already been promising results in patients with $\alpha$-SG deficiency $[145,146]$.

\section{Autologous and nonautologous cell-based therapies for $\delta$-SG deficiency}

Skeletal muscle is a source of myosphere-derived progenitor cells (MDPCs), which are multipotent cells that express a number of embryonic stem cell markers and differentiate into vascular smooth muscle cells and mesenchymal progeny. They have been shown to enhance neoangiogensis and restore $\delta$-SG expression in the vasculature of $S g c d^{-1-}$ mice [147]. MDPCs also promote secretion of paracrine effectors such as hepatocyte growth factor and stromal cell-derived factor 1, which are beneficial to cardiac function. Stem cells from patients can be pathologically impaired, however, such that other, nonautologous cell therapy approaches may be necessary.
Nonautologous cell therapy circumvents some problems associated with the quality and quantity of cells isolated for an autologous cell therapy approach. However, human leukocyte antigen incompatibility of nonautologous stem cells normally necessitates the use of immunosuppressive drugs, which have unattractive side effects. A recent study in TO-2 hamsters suggested that mesenchymal stem cells, which express a nonimmunogenic phenotype, may have potential as a source for nonautologous cell therapy that does not require immunosuppression [148]. Recently, intramyocardial injection with human umbilical cord mononuclear cells was shown to decrease fibrosis and increase short-term cardiac function in TO-2 hamsters [149]. Again, as with AAV gene transfer, approaches that have had success in animals may not be acceptable to the human immune system.

\section{Conclusions}

It is evident that $\delta$-SG deficiency causes a complex and multifactorial pathology for which a combinatorial therapeutic strategy may be necessary. The clinical manifestation of the disease is heterogeneous, with evidence of genetic modifiers. There are currently a number of potential therapeutic agents which target downstream defective pathways, but correction of the primary defect via gene or cell therapy may prove to be the most effective treatment strategy in the future. A focus on translational research is most important to ensure that patients benefit from our improved understanding of the pathophysiology implicated in $\delta$-SG deficiency.

Acknowledgements

AMB gratefully acknowledges the support of Heart Research UK and AFM.

\section{Authors' contributions}

$A M B$ and WWS participated in the research of the literature for this review and in the preparation of the manuscript and figures. Both authors read and approved the final manuscript.

\section{Competing interests}

The authors declare that they have no competing interests.

Received: 20 December 2010 Accepted: 17 March 2011

Published: 17 March 2011

\section{References}

1. Walton JN, Nattrass FJ: On the classification, natural history and treatment of the myopathies. Brain 1954, 77:169-231.

2. Hoffman EP, Brown RH Jr, Kunkel LM: Dystrophin: the protein product of the Duchenne muscular dystrophy locus. Cell 1987, 51:919-928.

3. Monaco AP, Neve RL, Colletti-Feener C, Bertelson CJ, Kurnit DM, Kunkel LM: Isolation of candidate cDNAs for portions of the Duchenne muscular dystrophy gene. Nature 1986, 323:646-650.

4. Campbell KP, Kahl SD: Association of dystrophin and an integral membrane glycoprotein. Nature 1989, 338:259-262.

5. Yoshida M, Noguchi S, Wakabayashi E, Piluso G, Belsito A, Nigro V, Ozawa E: The fourth component of the sarcoglycan complex. FEBS Lett 1997, 403:143-148 
6. Nigro V, Piluso G, Belsito A, Politano L, Puca AA, Papparella S, Rossi E, Viglietto G, Esposito MG, Abbondanza C, Medici N, Molinari AM, Nigro G, Puca GA: Identification of a novel sarcoglycan gene at $5 q 33$ encoding a sarcolemmal 35 kDa glycoprotein. Hum Mol Genet 1996, 5:1179-1186.

7. Nigro V, de Sá Moreira E, Piluso G, Vainzof M, Belsito A, Politano L, Puca AA, Passos-Bueno MR, Zatz M: Autosomal recessive limb-girdle muscular dystrophy, LGMD2F, is caused by a mutation in the $\delta$-sarcoglycan gene. Nat Genet 1996, 14:195-198.

8. Guglieri M, Magri F, D'Angelo MG, Prelle A, Morandi L, Rodolico C, Cagliani R, Mora M, Fortunato F, Bordoni A, Del Bo R, Ghezzi S, Pagliarani S, Lucchiari S, Salani S, Zecca C, Lamperti C, Ronchi D, Aguennouz M, Ciscato P, Di Blasi C, Ruggieri A, Moroni I, Turconi A, Toscano A, Moggio M, Bresolin N, Comi GP: Clinical, molecular, and protein correlations in a large sample of genetically diagnosed Italian limb girdle muscular dystrophy patients. Hum Mutat 2008, 29:258-266.

9. Politano L, Nigro V, Passamano L, Petretta V, Comi LI, Papparella S, Nigro G, Rambaldi PF, Raia P, Pini A, Mora M, Giugliano MA, Esposito MG, Nigro G: Evaluation of cardiac and respiratory involvement in sarcoglycanopathies. Neuromuscul Disord 2001, 11:178-185.

10. Fayssoil A: Cardiac diseases in sarcoglycanopathies. Int J Cardio/ 2010, 144:67-68.

11. Bushby K: Diagnosis and management of the limb girdle muscular dystrophies. Pract Neurol 2009, 9:314-323.

12. Fanin M, Duggan DJ, Mostacciuolo ML, Martinello F, Freda MP, Soraru G, Trevisan CP, Hoffman EP, Angelini C: Genetic epidemiology of muscular dystrophies resulting from sarcoglycan gene mutations. J Med Genet 1997, 34:973-977.

13. Norwood FL, Harling C, Chinnery PF, Eagle M, Bushby K, Straub V: Prevalence of genetic muscle disease in Northern England: in-depth analysis of a muscle clinic population. Brain 2009, 132:3175-3186.

14. Duggan DJ, Manchester D, Stears KP, Mathews DJ, Hart C, Hoffman EP: Mutations in the $\delta$-sarcoglycan gene are a rare cause of autosomal recessive limb-girdle muscular dystrophy (LGMD2). Neurogenetics 1997, 1:49-58.

15. Tsubata S, Bowles KR, Vatta M, Zintz C, Titus J, Muhonen L, Bowles NE, Towbin JA: Mutations in the human $\delta$-sarcoglycan gene in familial and sporadic dilated cardiomyopathy. J Clin Invest 2000, 106:655-662.

16. Trabelsi M, Kavian N, Daoud F, Commere V, Deburgrave N, Beugnet C, Llense S, Barbot JC, Vasson A, Kaplan JC, Leturcq F, Chelly J: Revised spectrum of mutations in sarcoglycanopathies. Eur J Hum Genet 2008, 16:793-803.

17. Honda T, Sugiyama S, Sakamoto T, Kaikita K, Ogawa H: Impact of $\delta$ sarcoglycan gene polymorphism on the occurrence of coronary spastic angina in Japanese patients with hypertrophic cardiomyopathy. Circ J 2007, 71:1263-1267.

18. Kärkkäinen $S$, Miettinen $R$, Tuomainen $P$, Kärkkäinen $P$, Heliö T, Reissell E, Kaartinen M, Toivonen L, Nieminen MS, Kuusisto J, Laakso M, Peuhkurinen K: A novel mutation, Arg71Thr, in the $\delta$-sarcoglycan gene is associated with dilated cardiomyopathy. J Mol Med 2003, 81:795-800.

19. Bauer R, Hudson J, Müller HD, Sommer C, Dekomien G, Bourke J, Routledge D, Bushby K, Klepper J, Straub V: Does $\delta$-sarcoglycan-associated autosomal-dominant cardiomyopathy exist? Eur J Hum Genet 2009, 17:1148-1153.

20. Chen J, Shi W, Zhang Y, Sokol R, Cai H, Lun M, Moore BF, Farber MJ, Stepanchick JS, Bönnemann CG, Chan YM: Identification of functional domains in sarcoglycans essential for their interaction and plasma membrane targeting. Exp Cell Res 2006, 312:1610-1625.

21. Liu LA, Engvall E: Sarcoglycan isoforms in skeletal muscle. J Biol Chem 1999, 274:38171-38176.

22. Chan YM, Bönnemann CG, Lidov HG, Kunkel LM: Molecular organization of sarcoglycan complex in mouse myotubes in culture. J Cell Biol 1998, 143:2033-2044.

23. Draviam RA, Shand SH, Watkins SC: The $\beta$ - $\delta$-core of sarcoglycan is essential for deposition at the plasma membrane. Muscle Nerve 2006, 34:691-701.

24. Shi W, Chen Z, Schottenfeld J, Stahl RC, Kunkel LM, Chan YM: Specific assembly pathway of sarcoglycans is dependent on $\beta$ - and $\delta$ sarcoglycan. Muscle Nerve 2004, 29:409-419.

25. Vainzof M, Passos-Bueno MR, Canovas M, Moreira ES, Pavanello RC, Marie SK, Anderson LV, Bönnemann CG, McNally EM, Nigro V, Kunkel LM,
Zatz M: The sarcoglycan complex in the six autosomal recessive limbgirdle muscular dystrophies. Hum Mol Genet 1996, 5:1963-1969.

26. Klinge L, Dekomien G, Aboumousa A, Charlton R, Epplen JT, Barresi R, Bushby K, Straub V: Sarcoglycanopathies: can muscle immunoanalysis predict the genotype? Neuromuscul Disord 2008, 18:934-941.

27. Straub V, Ettinger AJ, Durbeej M, Venzke DP, Cutshall S, Sanes JR, Campbell KP: $\varepsilon$-Sarcoglycan replaces a-sarcoglycan in smooth muscle to form a unique dystrophin-glycoprotein complex. J Biol Chem 1999, 274:27989-27996.

28. Durbeej M, Campbell KP: Biochemical characterization of the epithelial dystroglycan complex. J Biol Chem 1999, 274:26609-26616.

29. Wheeler MT, Zarnegar S, McNally EM: Z-sarcoglycan, a novel component of the sarcoglycan complex, is reduced in muscular dystrophy. Hum Mol Genet 2002, 11:2147-2154.

30. Anastasi G, Cutroneo G, Sidoti A, Rinaldi C, Bruschetta D, Rizzo G, D'Angelo R, Tarone G, Amato A, Favaloro A: Sarcoglycan subcomplex expression in normal human smooth muscle. J Histochem Cytochem 2007, 55:831-843.

31. Anastasi G, Cutroneo G, Sidoti A, Santoro G, D'Angelo R, Rizzo G, Rinaldi C, Giacobbe O, Bramanti P, Navarra G, Amato A, Favaloro A: Sarcoglycan subcomplex in normal human smooth muscle: an immunohistochemical and molecular study. Int J Mol Med 2005, 16:367-374.

32. Anastasi G, Cutroneo G, Trimarchi F, Rizzo G, Bramanti P, Bruschetta D, Fugazzotto D, Cinelli MP, Soscia A, Santoro G, Favaloro A: Sarcoglycans in human skeletal muscle and human cardiac muscle: a confocal laser scanning microscope study. Cells Tissues Organs 2003, 173:54-63.

33. Matsumura K, Saito F, Yamada H, Hase A, Sunada Y, Shimizu T: Sarcoglycan complex: a muscular supporter of dystroglycan-dystrophin interplay? Cell Mol Biol (Noisy-le-grand) 1999, 45:751-762.

34. Wakayama $Y$, Inoue $M$, Kojima $H$, Murahashi $M$, Shibuya S, Oniki $H$ : Localization of sarcoglycan, neuronal nitric oxide synthase, $\beta$ dystroglycan, and dystrophin molecules in normal skeletal myofiber: triple immunogold labeling electron microscopy. Microsc Res Tech 2001 55:154-163.

35. Fanin M, Tasca E, Nascimbeni AC, Angelini C: Sarcolemmal neuronal nitric oxide synthase defect in limb-girdle muscular dystrophy: an adverse modulating factor in the disease course? J Neuropathol Exp Neurol 2009, 68:383-390.

36. Grozdanovic Z, Baumgarten HG: Nitric oxide synthase in skeletal muscle fibers: a signaling component of the dystrophin-glycoprotein complex. Histol Histopathol 1999, 14:243-256.

37. Chen J, Skinner MA, Shi W, Yu QC, Wildeman AG, Chan YM: The 16 kDa subunit of vacuolar $\mathrm{H}^{+}$-ATPase is a novel sarcoglycan-interacting protein. Biochim Biophys Acta 2007, 1772:570-579.

38. Anastasi G, Cutroneo G, Rizzo G, Arco A, Santoro G, Bramanti P, Vitetta AG, Pisani A, Trimarchi F, Favaloro A: Sarcoglycan and integrin localization in normal human skeletal muscle: a confocal laser scanning microscope study. Eur J Histochem 2004, 48:245-252.

39. Anastasi G, Amato A, Tarone G, Vita G, Monici MC, Magaudda L: Distribution and localization of vinculin-talin-integrin system and dystrophin-glycoprotein complex in human skeletal muscle. Cells Tissues Organs 2003, 175:151-164.

40. Estrada FJ, Mornet D, Rosas-Vargas H, Angulo A, Hernández M, Becker V Rendón A, Ramos-Kuri M, Coral-Vázquez RM: A novel isoform of $\delta$ sarcoglycan is localized at the sarcoplasmic reticulum of mouse skeletal muscle. Biochem Biophys Res Commun 2006, 340:865-871.

41. Cai H, Erdman RA, Zweier L, Chen J, Shaw JH, Baylor KA, Stecker MM, Carey DJ, Chan YM: The sarcoglycan complex in Schwann cells and its role in myelin stability. Exp Neurol 2007, 205:257-269.

42. Groh S, Zong H, Goddeeris MM, Lebakken CS, Venzke D, Pessin JE, Campbell KP: Sarcoglycan complex: implications for metabolic defects in muscular dystrophies. J Biol Chem 2009, 284:19178-19182.

43. Fort P, Estrada FJ, Bordais A, Mornet D, Sahel JA, Picaud S, Vargas HR, CoralVázquez RM, Rendon A: The sarcoglycan-sarcospan complex localization in mouse retina is independent from dystrophins. Neurosci Res 2005 , 53:25-33.

44. Homburger F, Baker JR, Nixon CW, Wilgram G: New hereditary disease of Syrian hamsters: primary, generalized polymyopathy and cardiac necrosis. Arch Intern Med 1962, 110:660-662.

45. Jung D, Duclos F, Apostol B, Straub V, Lee JC, Allamand V, Venzke DP, Sunada Y, Moomaw CR, Leveille CJ, Slaughter CA, Crawford TO, 
McPherson JD, Campbell KP: Characterization of $\delta$-sarcoglycan, a novel component of the oligomeric sarcoglycan complex involved in limbgirdle muscular dystrophy. J Biol Chem 1996, 271:32321-32329.

46. Nigro V, Okazaki Y, Belsito A, Piluso G, Matsuda Y, Politano L, Nigro G, Ventura C, Abbondanza C, Molinari AM, Acampora D, Nishimura M, Hayashizaki Y, Puca GA: Identification of the Syrian hamster cardiomyopathy gene. Hum Mol Genet 1997, 6:601-607.

47. Straub V, Duclos F, Venzke DP, Lee JC, Cutshall S, Leveille CJ, Campbell KP: Molecular pathogenesis of muscle degeneration in the $\delta$-sarcoglycandeficient hamster. Am J Pathol 1998, 153:1623-1630.

48. Awad SS, Welty JD: Comparisons of hemodynamics throughout the life span of the Bio 14.6 cardiomyopathic with the F1B normal hamster. Comp Biochem Physiol A Comp Physiol 1990, 97:487-491.

49. Sakamoto A, Ono K, Abe M, Jasmin G, Eki T, Murakami Y, Masaki T, Toyooka T, Hanaoka F: Both hypertrophic and dilated cardiomyopathies are caused by mutation of the same gene, $\delta$-sarcoglycan, in hamster: an animal model of disrupted dystrophin-associated glycoprotein complex. Proc Natl Acad Sci USA 1997, 94:13873-13878.

50. Sakamoto A: Molecular pathogenesis of severe cardiomyopathy in the TO-2 hamster. Exp Clin Cardiol 2003, 8:143-146.

51. Minieri M, Zingarelli M, Shubeita H, Vecchini A, Binaglia L, Carotenuto F, Fantini C, Fiaccavento R, Masuelli L, Coletti A, Simonelli L, Modesti A, Di Nardo P: Identification of a new missense mutation in the mtDNA of hereditary hypertrophic, but not dilated cardiomyopathic hamsters. Mol Cell Biochem 2003, 252:73-81.

52. Heydemann A, Ceco E, Lim JE, Hadhazy M, Ryder P, Moran JL, Beier DR, Palmer AA, McNally EM: Latent TGF- $\beta$-binding protein 4 modifies muscular dystrophy in mice. J Clin Invest 2009, 119:3703-3712.

53. Swaggart KA, Heydemann A, Palmer AA, MCNally EM: Distinct genetic regions modify specific muscle groups in muscular dystrophy. Physiol Genomics 2011, 43:24-31.

54. Kawada T, Nakatsuru Y, Sakamoto A, Koizumi T, Shin WS, Okai-Matsuo Y, Suzuki J, Uehara Y, Nakazawa M, Sato H, Ishikawa T, Toyo-oka T: Strain- and age-dependent loss of sarcoglycan complex in cardiomyopathic hamster hearts and its re-expression by $\delta$-sarcoglycan gene transfer in vivo. FEBS Lett 1999, 458:405-408.

55. Gouveia TL, Kossugue PM, Paim JF, Zatz M, Anderson LV, Nigro V, Vainzof $M$ : A new evidence for the maintenance of the sarcoglycan complex in muscle sarcolemma in spite of the primary absence of $\delta$-SG protein. J Mol Med 2007, 85:415-420.

56. Hack AA, Lam MY, Cordier L, Shoturma DI, Ly CT, Hadhazy MA, Hadhazy MR, Sweeney HL, McNally EM: Differential requirement for individual sarcoglycans and dystrophin in the assembly and function of the dystrophin-glycoprotein complex. J Cell Sci 2000, 113:2535-2544.

57. Coral-Vazquez R, Cohn RD, Moore SA, Hill JA, Weiss RM, Davisson RL, Straub V, Barresi R, Bansal D, Hrstka RF, Williamson R, Campbell KP: Disruption of the sarcoglycan-sarcospan complex in vascular smooth muscle: a novel mechanism for cardiomyopathy and muscular dystrophy. Cell 1999, 98:465-474.

58. Bauer R, MacGowan GA, Blain A, Bushby K, Straub V: Steroid treatment causes deterioration of myocardial function in the $\delta$-sarcoglycandeficient mouse model for dilated cardiomyopathy. Cardiovasc Res 2008, 79:652-661.

59. Bauer R, Blain A, Greally E, Bushby K, Lochmüller H, Laval S, Straub V, MacGowan GA: Intolerance to $\beta$-blockade in a mouse model of $\delta$ sarcoglycan-deficient muscular dystrophy cardiomyopathy. Eur J Heart Fail 2010, 12:1163-1170.

60. Wansapura JP, Millay DP, Dunn RS, Molkentin JD, Benson DW: Magnetic resonance imaging assessment of cardiac dysfunction in $\delta$-sarcoglycan null mice. Neuromuscul Disord 2011, 21:68-73.

61. Poppe M, Cree L, Bourke J, Eagle M, Anderson LV, Birchall D, Brockington M, Buddles M, Busby M, Muntoni F, Wills A, Bushby K: The phenotype of limb-girdle muscular dystrophy type 21. Neurology 2003, 60:1246-1251.

62. Chambers SP, Anderson LV, Maguire GM, Dodd A, Love DR: Sarcoglycans of the zebrafish: orthology and localization to the sarcolemma and myosepta of muscle. Biochem Biophys Res Commun 2003, 303:488-495.

63. Dekkers LC, van der Plas MC, van Loenen PB, den Dunnen JT, van Ommen GJ, Fradkin LG, Noordermeer JN: Embryonic expression patterns of the Drosophila dystrophin-associated glycoprotein complex orthologs. Gene Expr Patterns 2004, 4:153-159.
64. Grisoni K, Martin E, Gieseler K, Mariol MC, Segalat L: Genetic evidence for a dystrophin-glycoprotein complex (DGC) in Caenorhabditis elegans. Gene 2002, 294:77-86

65. Allikian MJ, Bhabha G, Dospoy P, Heydemann A, Ryder P, Earley JU, Wolf MJ, Rockman HA, McNally EM: Reduced life span with heart and muscle dysfunction in Drosophila sarcoglycan mutants. Hum Mol Genet 2007, 16:2933-2943.

66. Cheng L, Guo XF, Yang XY, Chong M, Cheng J, Li G, Gui YH, Lu DR: $\delta$ Sarcoglycan is necessary for early heart and muscle development in zebrafish. Biochem Biophys Res Commun 2006, 344:1290-1299.

67. Guyon JR, Mosley AN, Jun SJ, Montanaro F, Steffen LS, Zhou Y, Nigro V, Zon LI, Kunkel LM: $\delta$-Sarcoglycan is required for early zebrafish muscle organization. Exp Cell Res 2005, 304:105-115.

68. Segalat L: Dystrophin and functionally related proteins in the nematode Caenorhabditis elegans. Neuromuscul Disord 2002, 12(Suppl 1):S105-S109.

69. Millay DP, Goonasekera SA, Sargent MA, Maillet M, Aronow BJ, Molkentin JD: Calcium influx is sufficient to induce muscular dystrophy through a TRPC-dependent mechanism. Proc Natl Acad Sci USA 2009, 106:19023-19028.

70. Mendell JR, Sahenk Z, Prior TW: The childhood muscular dystrophies: diseases sharing a common pathogenesis of membrane instability. J Child Neurol 1995, 10:150-159.

71. Li M, Dickson DW, Spiro AJ: Sarcolemmal defect and subsarcolemmal lesion in a patient with $\gamma$-sarcoglycan deficiency. Neurology 1998, 50:807-809.

72. Pestronk A, Parhad IM, Drachman DB, Price DL: Membrane myopathy: morphological similarities to Duchenne muscular dystrophy. Muscle Nerve 1982, 5:209-214

73. Kawada T, Hemmi C, Fukuda S, Tezuka A, Iwasawa K, Nakazawa M, Sato H, Toyo-oka T: Sarcolemmal fragility secondary to the degradation of dystrophin in dilated cardiomyopathy, as estimated by electron microscopy. Exp Clin Cardiol 2003, 8:67-70.

74. Sen LY, O'Neill M, Marsh JD, Smith TW: Myocyte structure, function, and calcium kinetics in the cardiomyopathic hamster heart. Am J Physiol 1990, 259:H1533-H1543.

75. Li GR, Ferrier GR, Howlett SE: Calcium currents in ventricular myocytes of prehypertrophic cardiomyopathic hamsters. Am J Physiol 1995, 268: H999-H1005.

76. Iwata Y, Katanosaka Y, Shijun Z, Kobayashi Y, Hanada H, Shigekawa M, Wakabayashi S: Protective effects of $\mathrm{Ca}^{2+}$ handling drugs against abnormal $\mathrm{Ca}^{2+}$ homeostasis and cell damage in myopathic skeletal muscle cells. Biochem Pharmacol 2005, 70:740-751.

77. Howlett SE, Rafuse VF, Gordon T: $\left[{ }^{3} \mathrm{H}\right]$-Nitrendipine binding sites in normal and cardiomyopathic hamsters: absence of a selective increase in putative calcium channels in cardiomyopathic hearts. Cardiovasc Res 1988, 22:840-846.

78. Tawada-Iwata Y, Imagawa T, Yoshida A, Takahashi M, Nakamura H, Shigekawa M: Increased mechanical extraction of T-tubule/junctional SR from cardiomyopathic hamster heart. Am J Physiol 1993, 264 : H1447-H1453.

79. Sen L, Smith TW: T-type $\mathrm{Ca}^{2+}$ channels are abnormal in genetically determined cardiomyopathic hamster hearts. Circ Res 1994, 75:149-155.

80. Bkaily G, Sculptoreanu A, Jacques D, Jasmin G: Increases of T-type $\mathrm{Ca}^{2+}$ current in heart cells of the cardiomyopathic hamster. Mol Cell Biochem 1997, 176:199-204

81. Suzuki S, Ohkusa T, Ono K, Sato T, Yoshida MA, Yano M, Takebayashi S, Matsuzaki M: Beneficial effects of the dual L- and T-type $\mathrm{Ca}^{2+}$ channel blocker efonidipine on cardiomyopathic hamsters. Circ J 2007, 71:1970-1976.

82. Villame J, Massicotte J, Jasmin G, Dumont L: Effects of mibefradil, a T- and L-type calcium channel blocker, on cardiac remodeling in the UM-X7.1 cardiomyopathic hamster. Cardiovasc Drugs Ther 2001, 15:41-48.

83. Paquette $F$, Jasmin G, Dumont $L$ : Cardioprotective efficacy of verapamil and mibefradil in young UM-X7.1 cardiomyopathic hamsters. CardiovasC Drugs Ther 1999, 13:525-530.

84. Ducret T, Vandebrouck C, Cao ML, Lebacq J, Gailly P: Functional role of store-operated and stretch-activated channels in murine adult skeletal muscle fibres. J Physiol 2006, 575:913-924.

85. Nakamura TY, Iwata Y, Sampaolesi M, Hanada H, Saito N, Artman M, Coetzee WA, Shigekawa M: Stretch-activated cation channels in skeletal 
muscle myotubes from sarcoglycan-deficient hamsters. Am J Physiol Cell Physiol 2001, 281:C690-C699.

86. Gervásio OL, Whitehead NP, Yeung EW, Phillips WD, Allen DG: TRPC1 binds to caveolin-3 and is regulated by Src kinase: role in Duchenne muscular dystrophy. J Cell Sci 2008, 121:2246-2255.

87. Ward ML, Williams IA, Chu Y, Cooper PJ, Ju YK, Allen DG: Stretch-activated channels in the heart: contributions to length-dependence and to cardiomyopathy. Prog Biophys Mol Biol 2008, 97:232-249.

88. Kuo TH, Tsang W, Wiener J: Defective $\mathrm{Ca}^{2+}$-pumping ATPase of heart sarcolemma from cardiomyopathic hamster. Biochim Biophys Acta 1987, 900:10-16.

89. Solares-Pérez A, Alvarez R, Crosbie RH, Vega-Moreno J, Medina-Monares J, Estrada FJ, Ortega A, Coral-Vazquez R: Altered calcium pump and secondary deficiency of $\gamma$-sarcoglycan and microspan in sarcoplasmic reticulum membranes isolated from $\delta$-sarcoglycan knockout mice. Cell Calcium 2010, 48:28-36.

90. Babick AP, Cantor EJ, Babick JT, Takeda N, Dhalla NS, Netticadan T: Cardiac contractile dysfunction in J2N-k cardiomyopathic hamsters is associated with impaired SR function and regulation. Am J Physiol Cell Physiol 2004, 287:C1202-C1208.

91. Thakar JH, Thede A, Strickland KP: On the ultrastructure of primary cultures of normal and dystrophic hamster tongue muscle. Muscle Nerve 1980, 3:340-344.

92. Makita T, Sasaki K: A possible mode of formation of mitochondrial dense bodies in cardiac muscle of a dystrophic hamster. Cytobios 1979, 25:183-192.

93. Fraysse B, Nagi SM, Boher B, Ragot H, Lainé J, Salmon A, Fiszman MY, Toussaint M, Fromes $Y: \mathrm{Ca}^{2+}$ overload and mitochondrial permeability transition pore activation in living $\delta$-sarcoglycan-deficient cardiomyocytes. Am J Physiol Cell Physiol 2010, 299:C706-C713.

94. Wrogemann K, Blanchaer MC, Thakar JH, Mezon BJ: On the role of mitochondria in the hereditary cardiomyopathy of the Syrian hamster. Recent Adv Stud Cardiac Struct Metab 1975, 6:231-241.

95. Wrogemann K, Nylen EG: Mitochondrial calcium overloading in cardiomyopathic hamsters. J Mol Cell Cardiol 1978, 10:185-195.

96. Markiewicz W, Wu SS, Parmley WW, Higgins CB, Sievers R, James TL, Wikman-Coffelt J, Jasmin G: Evaluation of the hereditary Syrian hamster cardiomyopathy by 31P nuclear magnetic resonance spectroscopy: improvement after acute verapamil therapy. Circ Res 1986, 59:597-604.

97. Markiewicz W, Wu S, Sievers R, Parmley WW, Higgins CB, James TL, Jasmin G, Wikman-Coffelt J: Influence of heart rate on metabolic and hemodynamic parameters in the Syrian hamster cardiomyopathy. Am Heart J 1987, 114:362-368.

98. Millay DP, Sargent MA, Osinska H, Baines CP, Barton ER, Vuagniaux G, Sweeney HL, Robbins J, Molkentin JD: Genetic and pharmacologic inhibition of mitochondrial-dependent necrosis attenuates muscular dystrophy. Nat Med 2008, 14:442-447.

99. York CM, Cantrell CR, Borum PR: Cardiac carnitine deficiency and altered carnitine transport in cardiomyopathic hamsters. Arch Biochem Biophys 1983, 221:526-533.

100. Kobayashi A, Masumura Y, Yamazaki N: L-Carnitine treatment for congestive heart failure: experimental and clinical study. Jpn Circ J 1992, 56:86-94.

101. Maresca P, Corsico N, Arrigoni-Martelli E, Mancinelli R, Manni E: Propionyl-Lcarnitine improves mechanical performance of papillary muscle from dilated cardiomyopathic hamsters. Ann N Y Acad Sci 1995, 752:207-209.

102. Vargiu R, Littarru GP, Faa G, Mancinelli R: Positive inotropic effect of coenzyme $Q_{10}, \omega-3$ fatty acids and propionyl-L-carnitine on papillary muscle force-frequency responses of BIO TO-2 cardiomyopathic Syrian hamsters. Biofactors 2008, 32:135-144.

103. Whitmer JT: L-Carnitine treatment improves cardiac performance and restores high-energy phosphate pools in cardiomyopathic Syrian hamster. Circ Res 1987, 61:396-408.

104. Yamashita T, Kobayashi A, Yamazaki N, Miura K, Shirasawa H: Effects of Lcarnitine and verapamil on myocardial carnitine concentration and histopathology of Syrian hamster BIO 14.6. Cardiovasc Res 1986, 20:614-620.

105. Vargiu R, Littarru GP, Fraschini M, Perinu A, Tiano L, Capra A, Mancinelli R: Enhancement of shortening velocity, power, and acto-myosin crossbridge (CB) kinetics following long-term treatment with propionylL-carnitine, coenzyme $Q_{10}$, and $\omega-3$ fatty acids in BIO TO-2 cardiomyopathic Syrian hamsters papillary muscle. Biofactors 2010, 36:229-239.

106. Keith ME, Ball A, Jeejeebhoy KN, Kurian R, Butany J, Dawood F, Wen WH, Madapallimattam A, Sole MJ: Conditioned nutritional deficiencies in the cardiomyopathic hamster heart. Can J Cardiol 2001, 17:449-458.

107. Jamall IS, Haldar D, Wadewitz AG: Effects of dietary selenium on lipid peroxidation, mitochondrial function and protein profiles in the heart of the myopathic Syrian golden hamster (BIO 14.6). Biochem Biophys Res Commun 1987, 144:815-820.

108. Sembrowich WL, Knudson MB, Gollnick PD: Muscle metabolism and cardiac function of the myopathic hamster following training. J Appl Physiol 1977, 43:936-941.

109. Ho KW, Carrow R, Taylor J, Roy R, Lindstrom J, Heusner W, Van Huss W: Effects of swimming on dystrophic Syrian hamster heart. Exp Pathol (Jena) 1975, 11:247-254.

110. Tatsuguchi M, Hiratsuka E, Machida S, Nishikawa T, Imamura S, Shimizu S, Nishimura M, Komuro I, Furutani Y, Furutani M, Nagao H, Komatsu K, Kasanuki $H$, Matsuoka R: Swimming exercise in infancy has beneficial effect on the hearts in cardiomyopathic Syrian hamsters. J Muscle Res Cell Motil 2004, 25:69-76.

111. Durbeej M, Sawatzki SM, Barresi R, Schmainda KM, Allamand V, Michele DE, Campbell KP: Gene transfer establishes primacy of striated vs. smooth muscle sarcoglycan complex in limb-girdle muscular dystrophy. Proc Natl Acad Sci USA 2003, 100:8910-8915.

112. Figulla HR, Vetterlein F, Glaubitz M, Kreuzer H: Inhomogenous capillary flow and its prevention by verapamil and hydralazine in the cardiomyopathic Syrian hamster. Circulation 1987, 76:208-216.

113. Factor SM, Minase T, Cho S, Dominitz R, Sonnenblick EH: Microvascular spasm in the cardiomyopathic Syrian hamster: a preventable cause of focal myocardial necrosis. Circulation 1982, 66:342-354.

114. Cohn RD, Durbeej M, Moore SA, Coral-Vazquez R, Prouty S, Campbell KP: Prevention of cardiomyopathy in mouse models lacking the smooth muscle sarcoglycan-sarcospan complex. J Clin Invest 2001, 107:R1-R7.

115. Sonnenblick EH, Fein F, Capasso JM, Factor SM: Microvascular spasm as a cause of cardiomyopathies and the calcium-blocking agent verapamil as potential primary therapy. Am J Cardiol 1985, 55:179B-184B.

116. Kobayashi A, Yamashita T, Kaneko M, Nishiyama T, Hayashi H, Yamazaki N: Effects of verapamil on experimental cardiomyopathy in the Bio 14.6 Syrian hamster. J Am Coll Cardiol 1987, 10:1128-1138.

117. Wheeler MT, Allikian MJ, Heydemann A, Hadhazy M, Zarnegar S, McNally EM: Smooth muscle cell-extrinsic vascular spasm arises from cardiomyocyte degeneration in sarcoglycan-deficient cardiomyopathy. J Clin Invest 2004, 113:668-675.

118. Shimizu T, Okamoto H, Watanabe M, Kumamoto H, Chiba S, Matsui Y, Sugawara T, Onozuka H, Mikami T, Kitabatake A: Altered microvasculature is involved in remodeling processes in cardiomyopathic hamsters. Jpn Heart J 2003, 44:111-126.

119. Johnson P, Hammer JL: Calpain and calpastatin levels in dystrophic hamster skeletal muscles. Int I Biochem 1988, 20:1227-1230.

120. Crosbie RH, Barresi R, Campbell KP: Loss of sarcolemma nNOS in sarcoglycan-deficient muscle. FASEB J 2002, 16:1786-1791.

121. Sanders DB, Kelley T, Larson D: The role of nitric oxide synthase/nitric oxide in vascular smooth muscle control. Perfusion 2000, 15:97-104.

122. Rando TA: Role of nitric oxide in the pathogenesis of muscular dystrophies: a "two hit" hypothesis of the cause of muscle necrosis. Microsc Res Tech 2001, 55:223-235.

123. Crespo MJ, Cruz N, Altieri PI, Escobales N: Enalapril and losartan are more effective than carvedilol in preventing dilated cardiomyopathy in the Syrian cardiomyopathic hamster. J Cardiovasc Pharmacol Ther 2008, 13:199-206.

124. Abraham SS, Osorio JC, Homma S, Wang J, Thaker HM, Liao JK, Mital S: Simvastatin preserves cardiac function in genetically determined cardiomyopathy. J Cardiovasc Pharmacol 2004, 43:454-461.

125. Crespo MJ, De Mello WC: Chronic administration of losartan plus hydrochlorothiazide improves vascular status in young cardiomyopathic hamsters. Eur J Pharmacol 2001, 420:133-141.

126. Shinohara T, Shimizu M, Yoshio H, Ino H, Taguchi T, Mabuchi H: Collagen synthesis by cultured cardiac fibroblasts obtained from cardiomyopathic hamsters. Jpn Heart J 1998, 39:97-108. 
127. Escobales N, Ramos JA, Santacana GE, Crespo MJ: Hemodynamic alterations in the coronary circulation of cardiomyopathic hamsters: age and Ang II-dependent mechanisms. J Card Fail 2009, 15:929-938.

128. Galla JH, Schneider G, Kotchen TA, Hayslett JP: Renin and aldosterone in the cardiomyopathic hamster in congestive heart failure. Endocrinology 1977, 101:389-395.

129. Araki T, Shimizu M, Yoshio H, Ino H, Mabuchi $H$, Takeda R: Effects of angiotensin-converting enzyme inhibitor and aldosterone antagonist on myocardial collagen in cardiomyopathic hamsters. Jpn Circ J 1995, 59:213-218.

130. De Mello WC, Specht P: Chronic blockade of angiotensin II AT1-receptors increased cell-to-cell communication, reduced fibrosis and improved impulse propagation in the failing heart. $J$ Renin Angiotensin Aldosterone Syst 2006, 7:201-205.

131. Mansoor AM, Honda M, Kuramochi T, Tanaka K, Morioka S, Takabatake T: Effects of ACE inhibition and beta-blockade on collagen remodelling in the heart of Bio 14.6 hamsters. Clin Exp Pharmacol Physiol 1996, 23:43-49.

132. Lecarpentier Y, Pery N, Coirault C, Scalbert E, Desche P, Suard I, Lambert F, Chemla D: Intrinsic alterations of diaphragm muscle in experimental cardiomyopathy. Am Heart J 1993, 126:770-776.

133. Peng H, Carretero OA, Vuljaj N, Liao TD, Motivala A, Peterson EL, Rhaleb NE: Angiotensin-converting enzyme inhibitors: a new mechanism of action. Circulation 2005, 112:2436-2445.

134. Sejerson T, Bushby K, TREAT-NMD EU Network of Excellence: Standards of care for Duchenne muscular dystrophy: brief TREAT-NMD recommendations. Adv Exp Med Biol 2009, 652:13-21.

135. Townsend D, Yasuda S, Li S, Chamberlain JS, Metzger JM: Emergent dilated cardiomyopathy caused by targeted repair of dystrophic skeletal muscle. Mol Ther 2008, 16:832-835.

136. Kawada T, Nakazawa M, Nakauchi S, Yamazaki K, Shimamoto R, Urabe M, Nakata J, Hemmi C, Masui F, Nakajima T, Suzuki J, Monahan J, Sato H, Masaki T, Ozawa K, Toyo-oka T: Rescue of hereditary form of dilated cardiomyopathy by rAAV-mediated somatic gene therapy: amelioration of morphological findings, sarcolemmal permeability, cardiac performances, and the prognosis of TO-2 hamsters. Proc Natl Acad SCi USA 2002, 99:901-906.

137. Li J, Dressman D, Tsao YP, Sakamoto A, Hoffman EP, Xiao X: rAAV vectormediated sarcogylcan gene transfer in a hamster model for limb girdle muscular dystrophy. Gene Ther 1999, 6:74-82.

138. Holt KH, Lim LE, Straub V, Venzke DP, Duclos F, Anderson RD, Davidson BL, Campbell KP: Functional rescue of the sarcoglycan complex in the BIO 14.6 hamster using $\delta$-sarcoglycan gene transfer. Mol Cell 1998, 1:841-848.

139. Ikeda Y, Gu Y, Iwanaga Y, Hoshijima M, Oh SS, Giordano FJ, Chen J, Nigro V, Peterson KL, Chien KR, Ross J Jr: Restoration of deficient membrane proteins in the cardiomyopathic hamster by in vivo cardiac gene transfer. Circulation 2002, 105:502-508.

140. Toyo-oka T, Kawada T, Xi H, Nakazawa M, Masui F, Hemmi C, Nakata J, Tezuka A, Iwasawa K, Urabe M, Monahan J, Ozawa K: Gene therapy prevents disruption of dystrophin-related proteins in a model of hereditary dilated cardiomyopathy in hamsters. Heart Lung Circ 2002, 11:174-181.

141. Li J, Wang D, Qian S, Chen Z, Zhu T, Xiao X: Efficient and long-term intracardiac gene transfer in $\delta$-sarcoglycan-deficiency hamster by adeno-associated virus-2 vectors. Gene Ther 2003, 10:1807-1813.

142. Goehringer C, Rutschow D, Bauer R, Schinkel S, Weichenhan D, Bekeredjian R, Straub V, Kleinschmidt JA, Katus HA, Müller OJ: Prevention of cardiomyopathy in $\delta$-sarcoglycan knockout mice after systemic transfer of targeted adeno-associated viral vectors. Cardiovasc Res 2009, 82:404-410.

143. Hoshijima M, Hayashi T, Jeon YE, Fu Z, Gu Y, Dalton ND, Ellisman MH, Xiao X, Powell FL, Ross J Jr: $\delta$-Sarcoglycan gene therapy halts progression of cardiac dysfunction, improves respiratory failure, and prolongs life in myopathic hamsters. Circ Heart Fail 2011, 4:89-97.

144. Ying Y, Müller OJ, Goehringer C, Leuchs B, Trepel M, Katus HA, Kleinschmidt JA: Heart-targeted adeno-associated viral vectors selected by in vivo biopanning of a random viral display peptide library. Gene Ther 2010, 17:980-990.

145. Mendell JR, Rodino-Klapac LR, Rosales-Quintero X, Kota J, Coley BD, Galloway G, Craenen JM, Lewis S, Malik V, Shilling C, Byrne BJ, Conlon T, Campbell KJ, Bremer WG, Viollet L, Walker CM, Sahenk Z, Clark KR: Limb- girdle muscular dystrophy type 2D gene therapy restores a-sarcoglycan and associated proteins. Ann Neurol 2009, 66:290-297.

146. Mendell JR, Rodino-Klapac LR, Rosales XQ, Coley BD, Galloway G, Lewis S, Malik V, Shilling C, Byrne BJ, Conlon T, Campbell KJ, Bremer WG, Taylor LE, Flanigan KM, Gastier-Foster JM, Astbury C, Kota J, Sahenk Z, Walker CM, Clark KR: Sustained a-sarcoglycan gene expression after gene transfer in limb-girdle muscular dystrophy, type 2D. Ann Neurol 2010, 68:629-638.

147. Nomura T, Ashihara E, Tateishi K, Asada S, Ueyama T, Takahashi T, Matsubara $\mathrm{H}, \mathrm{Oh} \mathrm{H}$ : Skeletal myosphere-derived progenitor cell transplantation promotes neovascularization in $\delta$-sarcoglycan knockdown cardiomyopathy. Biochem Biophys Res Commun 2007, 352:668-674.

148. Shabbir A, Zisa D, Leiker M, Johnston C, Lin H, Lee T: Muscular dystrophy therapy by nonautologous mesenchymal stem cells: muscle regeneration without immunosuppression and inflammation. Transplantation 2009, 87:1275-1282.

149. Henning RJ, Aufman J, Shariff M, Sawmiller D, DeLostia V, Sanberg P, Morgan M: Human umbilical cord blood mononuclear cells decrease fibrosis and increase cardiac function in cardiomyopathy. Regen Med 2010, 5:45-54.

150. Toyo-oka T, Kawada T, Nakata J, Xie H, Urabe M, Masui F, Ebisawa T, Tezuka A, Iwasawa K, Nakajima T, Uehara Y, Kumagai H, Kostin S, Schaper J, Nakazawa M, Ozawa K: Translocation and cleavage of myocardial dystrophin as a common pathway to advanced heart failure: a scheme for the progression of cardiac dysfunction. Proc Natl Acad Sci USA 2004, 101:7381-7385.

151. Nishizawa T, Iwase M, Kanazawa H, Ichihara S, Ichihara G, Nagata K, Obata K Kitaichi K, Yokoi T, Watanabe M, Tsunematsu T, Ishikawa Y, Murohara T, Yokota M: Serial alterations of $\beta$-adrenergic signaling in dilated cardiomyopathic hamsters: possible role of myocardial oxidative stress. Circ J 2004, 68:1051-1060

152. Hampton TG, Kale A, Amende I, McCue S, Bhagavan HN, VanDongen CG: Gait disturbances in BIO TO-2 hamster model for muscular dystrophy [abstract]. FASEB J 2008, 22:757, 32

153. Mitsuhashi S, Saito N, Watano K, Igarashi K, Tagami S, Shima H, Kikuchi K: Defect of $\delta$-sarcoglycan gene is responsible for development of dilated cardiomyopathy of a novel hamster strain, J2N-k: calcineurin/PP2B activity in the heart of J2N-k hamster. J Biochem 2003, 134:269-276.

154. Jasmin G, Bajusz E: Prevention of myocardial generation in hamsters with hereditary cardiomyopathy. Recent Adv Stud Cardiac Struct Metab 1975, 6:219-229

155. Hunter EG, Hughes V, White J: Cardiomyopathic hamsters, CHF 146 and CHF 147: a preliminary study. Can J Physiol Pharmacol 1984, 62:1423-1428.

doi:10.1186/2044-5040-1-13

Cite this article as: Blain and Straub: $\delta$-Sarcoglycan-deficient muscular dystrophy: from discovery to therapeutic approaches. Skeletal Muscle 2011 1:13.

\section{Submit your next manuscript to BioMed Central and take full advantage of:}

- Convenient online submission

- Thorough peer review

- No space constraints or color figure charges

- Immediate publication on acceptance

- Inclusion in PubMed, CAS, Scopus and Google Scholar

- Research which is freely available for redistribution

Submit your manuscript at www.biomedcentral.com/submit
C Biomed Central 